\title{
Use of Biotechnology for Multiplication of Curcuma longa L. plant during six subcultures
}

\author{
Koriesh, E. M.; Eman I. Moghazy; Abo El-Soud I.H and Hefni M. M. \\ Horticulture Department, Faculty of Agriculture, Suez Canal University, Ismailia, Egypt, 41522
}

Received: 6/9/2018

\begin{abstract}
The aim of this study was to set a protocol for the in vitro culture of Curcuma longa L. Sprouted bud explants of $C$. longa L. were explanted on Murashige and Skoog (MS) medium supplemented with different concentrations of 6-benzyladenine (BA) $0,1,3,5$, and $7 \mathrm{mg} \mathrm{l}^{-1}$ during six subcultures. The maximum number of multiplied shoots (8.60 and 8.70 shoots explant $\left.{ }^{-1}\right)$, was obtained in the medium containing $7 \mathrm{mg}^{-1} \mathrm{BA}^{\mathrm{A}} 4^{\text {th }}$ and $5^{\text {th }}$ subculture with (90 and $100 \%$ multiplication frequency) respectively. The optimum BA concentrations for maximum number of multiplication varied across subcultures. The $7 \mathrm{mg}^{-1}$ BA concentration at the late subculture $4^{\text {th }}, 5^{\text {th }}$ and $6^{\text {th }}$ produce highest values of (number of shoots, longest shoot, number of leaves and fresh weight). The maximum number of roots $\left(6.38\right.$ roots explant $\left.{ }^{-1}\right)$ was induced from $3 \mathrm{mg} \mathrm{l}^{-1} \mathrm{IBA}$. The tallest roots $(40.6$ and $36.5 \mathrm{~cm})$ were obtained on MS medium supplemented with $1 \mathrm{mg} \mathrm{l}^{-1} \mathrm{NAA}$ and $3 \mathrm{mg} \mathrm{l}^{-1}$ IBA. Also, the heaviest fresh weight was obtained from medium containing 2 and $3 \mathrm{mg} \mathrm{l}^{-1}$ IBA and all concentrations of NAA. In vitro plantlets immediately acclimatized to greenhouse conditions, showing 100\% survival rates in a peat moss and vermiculite (1:3) medium.
\end{abstract}

Keywords: Turmeric, in vitro, Mass production, subculture

\section{INTRODUCTION}

Zingiberaceae is comprised of about 52 genera and over than 1,600 species that is widely distributed in the humid tropics subtropics and some seasonably dry regions of the world (Ravindran et al., 2007; Christenhusz and Byng, 2016). Of these genera, $C$. longa $\mathrm{L}$. is one of the most important plants that is represented by 120 species (Sumathi, 2014; Chen et al., 2015). Turmeric (C. longa L.) has been an important source of spice, dye and medicine for worldwide in the present and for traditional people throughout the ages (Deb and Chakraborty, 2017; Lamo and Rao, 2017). It is extremely nutritious, containing vitamins such as Betaine, Vitamin A and C, Folate and Choline and the minerals such as calcium, phosphorus, iron, zinc, magnesium, potassium and sodium (Yadav and Tarun, 2017). Besides, turmeric contains over than 235 compounds. Traditionally, turmericis vegetatively propagated from axillary branches "fingers or rhizomes", which commercially are called seed rhizomes. Propagation from seed rhizomes faced several problems for many reasons:

- Seed rhizomes have 1 or 2 buds, takes from 8 to 10 months to fully mature and become dormant over winter, even in tropical climates (Ghosh et al., 2013; Ravindran, 2017).

- About 20 to $30 \%$ of whole production was needed for the next season with high cost, low productivity and disease susceptibility of seed rhizomes (Goyal et al., 2010; Antoniazzi et al., 2016).

- Flowers don't produce viable seeds because of their natural sterility (triploid $2 \mathrm{n}=63$ ), mutations over period of the time, low fertility, natural seed set and environmental problems (Cheethaparambil et al., 2014; Raju et al., 2015).

Biotechnology is excellent tool for solving of turmeric production problems because it improves the crop and evolves the conventional breeding programs. In last few years, using of biotechnological tools have a quantum jump in commercial propagation and opened many possible ways in agriculture. Tools of agriculture biotechnology are solving the different problems, growing organisms, somaclonal variation, novel varieties and genetically engineered plants through tissue culture (Herdt, 2006; Ravindran et al., 2007; Ravindran and Babu, 2016).

Obtaining an aseptic culture from underground explant is difficult due to high contamination. Rhizomes and leaves are the major parts affected by microbial diseases causing economic and yield losses ranged from 50 to $60 \%$ in turmeric and their control is difficult. Like Zingiberaceae family, turmeric suffers from some disease problems in all turmeric-growing countries depending upon region and environmental condition from generation to other (Ravindran et al., 2007; Jasim et al., 2014; Sarathi et al., 2014; Ilyas et al., 2016).

Unfortunately, $C$. longa $\mathrm{L}$. often presents a challenge to producers since it may be infected with many pathogens. Fungi such as Pythium and Fusarium, bacteria such as Ralstonia Sp., Pseudomonas Sp., Bacillus sp., Staphylococcus sp. and sot rot bacteria (Erwinia carotovora) and nematodes such as Meloidogyne spp. are the most frequent pathogens found on the surface and inside underground plant parts (Anoop et al., 2014; Ajitomi et al., 2015; Prabhu et al., 2018).

The use of plant tissue culture technique as a biotechnological application of agriculture is more promising than other conventional propagation methods of $C$. longa L. plant. The objective of this study is to establish a micropropagation protocol for C. longa $\mathrm{L}$. plants in Egypt.

\section{MATERIALS AND METHODS}

This work was carried out in the Plant Tissue Culture Laboratory, of Horticulture Department, Faculty of Agriculture, Suez Canal University (SCU), Ismailia Governorate, Egypt, during the period from 2013 to 2015. 


\section{Plant materials}

Turmeric rhizomes (seed rhizome) were collected from local market and used as a plant material. Morphological identification was performed at the Herbarium of Botany Dep., Fac. of Science, SCU., then confirmed using molecular identification tools by in Institute of Biotechnology for Postgraduate Studies and Research, SCU, Egypt.

\section{Establishment of aseptic explant}

Sprout bud explants were surface cleaned. Explants were excised with blade and washed with running tap water for 30 minutes. Disinfestation was performed with commercial systematic fungicide known as Sogaat ${ }^{\mathrm{TM}}$ $72 \%$ wet powder (SO)containing Mancozeb $64 \%+$ Metalaxyl 8\% WP (Al-Ezz Group Comp.) 45 min. and mercury chloride $\mathrm{HgCl}_{2}$ for $7 \mathrm{~min}$. and finally washed 3 times with distilled sterilized water.

Explants were cultured vertically into MS medium fortified with different concentrations of 6benzyladenine (BA) at $0,1,3,5$, and $7 \mathrm{mg} \mathrm{l}^{-1}$ on multiplication during six subcultures.

\section{Shoot initiation and multiplication}

This experiment was designed to investigate the effect of BA concentrations $\left(0,1,3,5\right.$, and $\left.7 \mathrm{mg}^{-1}\right)$ on multiplication during six subcultures. One sprout buds were used as explants in each culture jars, and the in vitro multiplied shoots were sub-cultured every 8 weeks. Each jar contained $40 \mathrm{ml}$ MS medium (Murashige and Skoog 1962) supplemented with $30 \mathrm{~g} \mathrm{l}^{-1}$ sucrose, solidified with $7 \mathrm{~g}^{-1}$ agar and $\mathrm{pH}$ was adjusted to $5.7 \pm 0.1$. The cultural jars were immediately capped with polypropylene closure and autoclaved at $121^{\circ} \mathrm{C}$ at $1.5 \mathrm{Kg} / \mathrm{cm}^{2}$ for $20 \mathrm{~min}$. The jars were then placed in growth room at 16/8-hour photoperiod with 3000 lux $\left(45 \mu \mathrm{mol} \mathrm{m} \mathrm{m}^{-2} \mathrm{~s}^{-1}\right)$ light at $23 \pm 2^{\circ} \mathrm{C}$ day temperature. The data were record every 8 weeks after each subculture.

\section{In vitro rooting of $C$. longa $\mathrm{L}$.}

This experiment was carried out to examine the optimal auxin from IAA, IBA and NAA and its concentrations for the in vitro rooting of multiplied shoot of $C$. longa L. Multiplied shoot were cultured onto MS medium supplemented with sucrose at $30 \mathrm{~g} \mathrm{l}^{-1}$ and solidified with agar at $6 \mathrm{~g} \mathrm{l}^{-1}$. IAA, IBA and NAA were added individually to the medium at concentration of $0,1,2$ and $3 \mathrm{mg} \mathrm{l}^{-1}$. The cultures were incubated in the growth room under photo periodic cycle of $16 / 8$ hrs. as light/ dark and $23 \pm 2{ }^{\circ} \mathrm{C}$. The data were record after 4 weeks.

\section{Acclimatization}

Rooted plantlets were washed under running tap water to remove agar on the roots. Thoroughly, plantlets were soaked in fungicide solution contains $2.0 \mathrm{~g}^{-1}$ Sogaatfor 10 seconds. The plantlets were individually transplanted into $5.0 \mathrm{~cm}$ plastic pots containing peatmoss + vermiculite $(1: 3)$. Pots were covered with transparent plastic sheets and mist irrigated daily for a week. Misting was decreased until plantlets were fully acclimatized after four weeks. Plants were re-cultured into large plastic pots $(20 \mathrm{~cm})$ containing sand. During this period, the plants were watered when needed with tap water and once per week with compound fertilizer which consisted of $\mathrm{N}$ : P: $\mathrm{K}(20: 20: 20)+1 \mathrm{MgO}+$ micro elements with irrigation water.

Data analysis or Statistical analysis:

Data were computerized and subjected to statistical analysis using SPSS "version 19" statistical software according to McDonald (2014).Statistical differences between the means were tested using LSD at 5\% level of probability according to Gomez and Gomez (1984).

\section{RESULTS AND DISCUSSION}

\section{The main effects of $B A$ concentrations}

The main effect of BA concentrations had a significant effect on the number of shoots, longest shoot, number of leaves, fresh weight and base diameter.

Data in Table (1a) indicate that $7 \mathrm{mg}^{-1} \mathrm{BA}$ significantly produced the greatest number of shoots (5.78 shoots explant $\left.{ }^{-1}\right)$, longest shoot $(10.8 \mathrm{~cm})$, number of leaves (20.8 leaves explant $\left.{ }^{-1}\right)$, plantlet fresh weight $(7.50 \mathrm{~g})$ and base diameter $(4.12 \mathrm{~mm})$. In addition, the control has lower values of all parameters.

\section{The main effects of six subcultures}

The cultures were sub-cultured every 8 weeks using the same type of media, until the $6^{\text {th }}$ subculture and the effect of six subcultures were analyzed with all parameters. The data in Table (1a) revealed that the $5^{\text {th }}$ subculture significantly increased the number of shoots (5.42 shoots explant $\left.{ }^{-1}\right)$ and fresh weight (5.56 g). On the other hand, the $6^{\text {th }}$ subculture produced the highest values of the shoot length $(12.04 \mathrm{~cm})$, number of leaves (23.0 leaves explant ${ }^{-1}$ ) and base diameter 4.31 $\mathrm{mm}$. The results could then be used to guide later experiments to study the stability of every subculture genome.

\section{The interaction effects between BA concentrations and subcultures}

The same mother explant was subculture on MS medium supplemented with different concentrations of BA until six subcultures. Statistical analysis showed significant differences for interaction effects between BA concentration and subcultures for all studies characters as shown in Table (1b) and Fig. (1). Multiplication frequency $\%$ was calculated for each BA concentration during six subcultures is shown in Table (1b). The Multiplication frequencies are in the range of 75 to $100 \%$.

Absence of BA produces minimum number of multiple shoots in the range 1.0 to 1.4 shoots explant ${ }^{-1}$, through all six subcultures. On other hand, the maximum number of multiplied shoots (8.6 and 8.7 shoots explant $\left.{ }^{-1}\right)$, was obtained in the medium containing $7 \mathrm{mg} \mathrm{l}^{-1} \mathrm{BA}$ at $4^{\text {th }}$ and $5^{\text {th }}$ subculture with 90 and $100 \%$ multiplication frequency, respectively.

Data in same Table (1b) show that the minimum number of leaves was produced in the medium without BA in all subcultures, but the maximum number of leaves (34.6 leaves explant ${ }^{-1}$ ) was obtained in the medium supplemented with $5 \mathrm{mg} \mathrm{l}^{-1} \mathrm{BA}$ in $6^{\text {th }}$ subculture without any differences than medium containing $7 \mathrm{mg} \mathrm{l}^{-}$ 
${ }^{1} \mathrm{BA}$ in $5^{\text {th }}, 4^{\text {th }}$ and $6^{\text {th }}$ subcultures $(30.2,29.8$ and 29.8 leaves explant ${ }^{-1}$ ) respectively. The BA concentrations at $0,1,3$, and $7 \mathrm{mg} \mathrm{l}^{-1}$ in the first subculture produced the shortest shoot than $5 \mathrm{mg}^{-1} \mathrm{BA}$ in the same subculture. In contrast, the tallest shoots $(13.7$ and $13.80 \mathrm{~cm})$ was obtained in the medium supplemented with 1 and $7 \mathrm{mg}$ $1^{-1}$ BA in $5^{\text {rd }}$ subculture respectively as shown in Table (1b).

Absence of BA resulted in least values of fresh weight at all subcultures while the highest concentration $7 \mathrm{mg} \mathrm{l}^{-1}$ BA produce heaviest fresh weight at the last subcultures $\left(4^{\text {th }}, 5^{\text {th }}\right.$ and $6^{\text {th }}$ subculture $)$. MS medium supplemented with $7 \mathrm{mg}^{-1} \mathrm{BA}$ was found to be the most effective concentration for fresh weight 11.0 gat the $5^{\text {th }}$ subculture and least value 1.55 gat absence of BA in the first subculture as shown in Table (1b).

Concerning shoot base diameter, there was a significant difference between BA concentrations at different subcultures. clearly the data showed that the biggest base diameters were produced as follow: at the $6^{\text {th }}$ subcultures in medium supplemented with 0,5 and 7 $\mathrm{mg}^{-1}$ BA $(3.50,5.56$ and $4.93 \mathrm{~mm})$ respectively and at the $3^{\text {rd }}$ subculture in medium containing 1 and $3 \mathrm{mg}^{-1}$ BA (4.24 and $4.83 \mathrm{~mm}$ ) respectively. The greatest value of multiple shoot base diameter $(5.35 \mathrm{~mm})$ were obtained from MS medium supplemented with $5 \mathrm{mg}^{-1}$ $\mathrm{BA}$ in $6^{\text {th }}$ generation and the least values at the first subculture in absence of BA.

The optimum BA concentrations for maximum multiplication varied across subcultures or different subcultures. In this process the tissue or explant is first subdivide, then transferred into fresh culture medium. The $7 \mathrm{mg} \mathrm{l}^{-1}$ BA concentration at the subcultures $4^{\text {th }}, 5^{\text {th }}$ and $6^{\text {th }}$ produce highest values of number of shoots, tallest shoots, number of leaves and heaviest fresh weight. This observation was confirmed by Sunitibala et al. (2001), who found that plantlets obtained after each subculture (as total 20 subculture) appeared healthy even after eleven or twelve subcultures. Besides, results in an average tenfold increase in shoot numbers per monthly culture subculture. On the same hand, Yusuf et al. (2011) found that the number of multiple shoots was low during first subculture but increased in third subculture and slightly decreased after fourth subculture for Boesenbergia rotunda L. (Zingiberaceae family) from sprouted bud explant.

Another successful result has been obtained by Khalafalla et al. (2011). They found that the maximum mean number of shoots per explant $(86.5 \pm 3.6)$ was produced after three multiplication cycles on $3 \mathrm{mg} / \mathrm{L}$ BA-supplemented medium. In vitro induced shoots were excised and rooted on half strength MS medium fortified with $0.25 \mathrm{mg} \mathrm{l}^{-1} \mathrm{IBA}$ to obtain complete plantlets of Boscia senegalensis regenerated plantlets obtained in vitro for the first time, were hardened and 95\% survived under greenhouse conditions. Also, Selvakkumar et al. (2007) when cultured the explants excised from sub-culturing shoots of Alpinia officinarum on the same fresh medium, found that during the 5-6 subculture the percentage of shoot development as well as the number of shoots per explant retained the same value (8.5 and 5.6 shoot explant $^{-1}$ ) and (3.3 and $\left.4.2 \mathrm{~cm} \mathrm{explant}^{-1}\right)$ for shoot length. Such type of simultaneous production of multiple shoot was reported earlier for a few medicinal plant species (Mohanty et al., 2013). In addition, similar results were reported on banana by Al-Amin et al. (2009) and Bhosale et al. (2011) who found that addition of BA at $7.5 \mathrm{mg} \mathrm{l}^{-1}$ to MS medium enhanced the production of multiple shoots and maximum number of leaves.

Table (1a): Main effects of BA concentrations and subcultures on number of shoots, length of shoot, number of leaves, fresh weight and base diameter of C. longa L. during six subcultures (sprout bud explants)

\begin{tabular}{|c|c|c|c|c|c|}
\hline & No. of shoots explant $_{1}^{-}$ & $\begin{array}{c}\text { Length of shoot } \\
(\mathrm{cm})\end{array}$ & $\begin{array}{c}\text { No. of leaves explant }^{-} \\
\end{array}$ & $\begin{array}{c}\text { Fresh weight } \\
\text { (g) }\end{array}$ & $\begin{array}{c}\text { Base diameter } \\
(\mathrm{mm})\end{array}$ \\
\hline \multicolumn{6}{|c|}{$\mathrm{BA}\left(\mathrm{mg} \mathrm{l}^{-1}\right)$} \\
\hline $\mathbf{0}$ & 1.25 & 9.95 & 3.35 & 2.00 & 2.90 \\
\hline 1 & 4.12 & 10.2 & 17.0 & 4.35 & 3.69 \\
\hline 3 & 4.48 & 9.22 & 17.7 & 4.46 & 3.71 \\
\hline 5 & 3.78 & 9.67 & 17.1 & 4.19 & 3.82 \\
\hline 7 & 5.78 & 10.7 & 20.9 & 7.50 & 4.12 \\
\hline \multicolumn{6}{|c|}{ subcultures } \\
\hline 1 & 2.46 & 5.40 & 8.88 & 2.74 & 3.22 \\
\hline 2 & 2.70 & 10.3 & 11.8 & 4.06 & 3.64 \\
\hline 3 & 3.18 & 10.5 & 11.0 & 4.16 & 3.67 \\
\hline 4 & 5.00 & 10.0 & 17.0 & 5.25 & 3.15 \\
\hline 5 & 5.42 & 11.4 & 19.6 & 5.56 & 3.90 \\
\hline 6 & 4.54 & 12.0 & 23.0 & 5.23 & 4.31 \\
\hline & $\begin{array}{ll}\text { D 5\% } \\
\text { factor }\end{array}$ & 0.59 & 1.82 & 0.48 & 0.32 \\
\hline & $\begin{array}{ll}\text { D 5\% } & 0.44 \\
\text { factor }\end{array}$ & 0.64 & 1.99 & 0.53 & 0.35 \\
\hline
\end{tabular}

Means with the same letters in the same column are not significantly different according to least significant difference test (LSD) $5 \%$ 
Table (1b): Interaction effects of BA concentrations and subcultures on number of shoots, length of longest shoot, number of leaves, fresh weight and base diameter of $C$. longa L. during six subcultures (sprout bud explants)

\begin{tabular}{|c|c|c|c|c|c|c|c|}
\hline $\begin{array}{c}\text { BA(mg } \\
\left.\mathrm{I}^{-1}\right)\end{array}$ & Subcultures & $\begin{array}{l}\text { multiplication } \\
\text { frequency } \%\end{array}$ & $\begin{array}{c}\text { No. of } \\
\text { shoots } \\
\text { explant }^{-1}\end{array}$ & $\begin{array}{l}\text { Length of } \\
\text { longest } \\
\text { shoot }(\mathrm{cm})\end{array}$ & $\begin{array}{c}\text { No. of } \\
\text { leaves } \\
\text { explant }^{-1}\end{array}$ & $\begin{array}{c}\text { Fresh } \\
\text { weight (g) }\end{array}$ & $\begin{array}{c}\text { Base } \\
\text { diameter } \\
(\mathrm{mm})\end{array}$ \\
\hline \multirow{7}{*}{0} & $1^{\mathrm{st}}$ & 75 & 1.00 & 5.50 & 2.40 & 1.55 & 2.20 \\
\hline & $2^{\text {nd }}$ & 75 & 1.20 & 9.30 & 3.40 & 2.01 & 2.55 \\
\hline & $3^{\text {rd }}$ & 75 & 1.20 & 11.8 & 3.00 & 1.83 & 2.60 \\
\hline & $4^{\text {th }}$ & 100 & 1.40 & 11.7 & 3.00 & 2.14 & 3.22 \\
\hline & $5^{\text {th }}$ & 100 & 1.40 & 10.0 & 3.80 & 2.14 & 3.30 \\
\hline & $6^{\text {th }}$ & 100 & 1.30 & 11.4 & 4.50 & 2.32 & 3.50 \\
\hline & $1^{\text {st }}$ & 80 & 3.00 & 5.00 & 9.90 & 2.29 & 3.05 \\
\hline \multirow{5}{*}{1} & $2^{\text {nd }}$ & 80 & 3.20 & 10.4 & 17.3 & 4.93 & 3.67 \\
\hline & $3^{\text {rd }}$ & 100 & 3.30 & 8.90 & 14.5 & 4.46 & 4.24 \\
\hline & $4^{\text {th }}$ & 100 & 5.20 & 11.5 & 16.6 & 4.76 & 3.39 \\
\hline & $5^{\text {th }}$ & 100 & 6.60 & 13.7 & 26.4 & 5.53 & 3.75 \\
\hline & $6^{\text {th }}$ & 100 & 3.40 & 11.7 & 17.5 & 4.14 & 4.02 \\
\hline \multirow{6}{*}{3} & $1^{\text {st }}$ & 80 & 2.50 & 3.30 & 10.6 & 2.87 & 2.95 \\
\hline & $2^{\text {nd }}$ & 80 & 2.70 & 10.1 & 11.5 & 4.31 & 4.12 \\
\hline & $3^{\text {rd }}$ & 80 & 2.90 & 7.70 & 11.9 & 3.88 & 4.83 \\
\hline & $4^{\text {th }}$ & 80 & 6.30 & 7.90 & 21.0 & 5.78 & 2.89 \\
\hline & $5^{\text {th }}$ & 100 & 6.80 & 13.2 & 22.6 & 5.56 & 3.95 \\
\hline & $6^{\text {th }}$ & 100 & 5.70 & 13.1 & 28.8 & 4.35 & 3.54 \\
\hline \multirow{6}{*}{5} & $1^{\text {st }}$ & 80 & 2.80 & 8.70 & 11.2 & 3.57 & 3.42 \\
\hline & $2^{\text {nd }}$ & 80 & 3.10 & 10.6 & 14.9 & 3.42 & 3.56 \\
\hline & $3^{\text {rd }}$ & 100 & 3.10 & 11.7 & 12.1 & 4.08 & 3.52 \\
\hline & $4^{\text {th }}$ & 90 & 3.50 & 8.40 & 14.5 & 3.78 & 2.81 \\
\hline & $5^{\text {th }}$ & 90 & 3.60 & 6.20 & 15.1 & 3.57 & 4.07 \\
\hline & $6^{\text {th }}$ & 100 & 6.60 & 12.4 & 34.6 & 6.72 & 5.56 \\
\hline \multirow{6}{*}{7} & $1^{\text {st }}$ & 70 & 3.00 & 4.50 & 10.3 & 3.43 & 4.48 \\
\hline & $2^{\text {nd }}$ & 80 & 3.30 & 11.1 & 11.9 & 5.63 & 4.32 \\
\hline & $3^{\text {rd }}$ & 90 & 5.40 & 12.6 & 13.3 & 6.54 & 3.16 \\
\hline & $4^{\text {th }}$ & 80 & 8.60 & 10.6 & 29.8 & 9.80 & 3.44 \\
\hline & $5^{\text {th }}$ & 100 & 8.70 & 13.8 & 30.2 & 11.0 & 4.41 \\
\hline & $6^{\text {th }}$ & 80 & 5.70 & 11.6 & 29.8 & 8.60 & 4.93 \\
\hline \multicolumn{2}{|c|}{ LSD 5\% } & & 0.98 & 1.44 & 4.46 & 1.19 & 0.78 \\
\hline
\end{tabular}

Means with the same letters in the same column are not significantly different according to least significant difference test (LSD) $5 \%$

\section{In vitro rooting of $C$. longa $\mathrm{L}$.}

Multiplied plantlets of $C$. longa L. were cultured individually on MS medium supplemented with different concentrations of auxin types IAA, IBA and NAA at the concentrations of $0,1,2$ and $3 \mathrm{mg} 1^{-1}$. Presented data in Table (2) show that MS medium supplemented with or without auxin types produced $100 \%$ of rooting.

Data present in Table (2) show that the maximum number of roots (6.38 roots/explant) was induced from medium supplemented with $3 \mathrm{mg}^{-1}$ IBA. In addition, NAA at $1 \mathrm{mg}^{-1}$ and IBA at 2 and $3 \mathrm{mg} \mathrm{l}^{-1}$ produced the tallest plantlets as 20.0, 20.2 and $19.4 \mathrm{~cm}$, and longest roots as $40.9,36.5$ and $34.7 \mathrm{~cm}$, respectively. The tallest roots (40.6 and $36.5 \mathrm{~cm}$ ) were obtained from MS medium supplemented with $1 \mathrm{mg} \mathrm{l}^{-1} \mathrm{NAA}$ and $3 \mathrm{mg} \mathrm{l}^{-1}$ IBA. Also, the heaviest fresh weight was obtained from medium containing 2 and $3 \mathrm{mg} \mathrm{l}^{-1}$ IBA and all concentration of NAA.

Generally, in multiplied shoots of $C$. longa L. there was no significant effect between both IBA and IAA and the control treatment. So, we support that using of free-hormone medium to in vitro rooting stage. The plantlets rooted with IAA and IBA and also those produced without auxins survived well in soil as long and hardy. In respect to the studies of Das et al. (2010)Ghosh et al.(2013) and Babu et al. (2016) and others who mentioned to use NAA and IBA for in vitro rooting. Several studies reported that irrespective BA concentrations resulted in prolific root system in culture medium as mentioned by Ravindran et al.(2007). Also, Bhattacharya et al. (2014) mentioned that plant growth regulator may or may not be required for in vitro rooting and absence of PGRs in medium rooted well of $C$. zedoria, Z. zerumbet, Z. zedoaria, A. galangal, and others.

\section{Acclimatization}

Plantlets were washed under running tap water to remove agar on the roots. Thoroughly, plantlets were soaked in fungicide solution $(0.2 \%)$. Plantlets were acclimatized in the greenhouse for 30 days and $100 \%$ of plants survived and had normal growth after transferring them to the field during the planting season. 


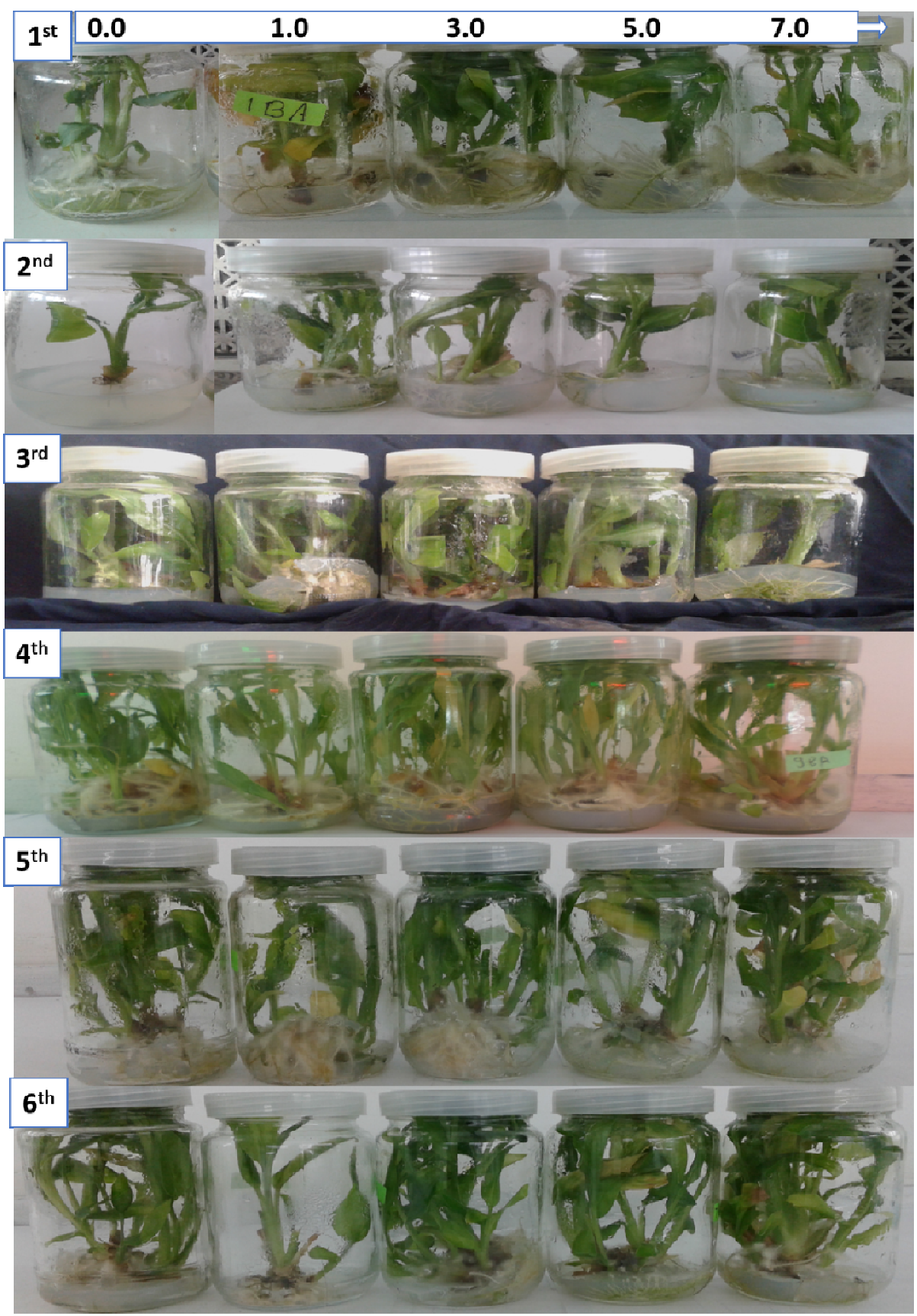

Figure (1): Multiplied shoots induction of C. longa L. (a) first subculture ( $\left.1^{\text {st }}\right)$ (b) second subculture $\left(2^{\text {nd }}\right)$ (c) third subculture $\left(3^{\text {rd }}\right)$ (d) fourth subculture $\left(4^{\text {th }}\right)$ (e) fifth subculture $\left(5^{\text {th }}\right)(f)$ sixth subculture $\left(6^{\text {th }}\right)$ 
Table (2): Effects of IAA, IBA and NAA concentrations on in vitro rooting of $C$. longa $\mathrm{L}$

\begin{tabular}{|c|c|c|c|c|c|c|c|}
\hline$\underset{\mathbf{I}^{-1}}{\text { IAA }} \mathbf{m g}$ & $\underset{\mathrm{I}^{-1}}{\text { IBA mg }}$ & $\underset{\mathbf{I}^{-1}}{\text { NAA }} \mathbf{m g}$ & $\begin{array}{c}\text { Rooting } \\
\%\end{array}$ & $\begin{array}{c}\text { No. of } \\
\text { roots/explant }\end{array}$ & $\begin{array}{l}\text { Root length } \\
\text { (cm) }\end{array}$ & $\begin{array}{l}\text { Plantlets height } \\
\text { (cm) }\end{array}$ & $\begin{array}{c}\text { Fresh } \\
\text { weight }(g)\end{array}$ \\
\hline 0 & 0 & 0 & \multirow{10}{*}{100} & 5.20 & 23.9 & 15.0 & 7.94 \\
\hline 1 & $\mathbf{0}$ & $\mathbf{0}$ & & 4.25 & 20.8 & 17.0 & 8.65 \\
\hline 2 & $\mathbf{0}$ & $\mathbf{0}$ & & 3.38 & 16.5 & 13.8 & 7.05 \\
\hline 3 & $\mathbf{0}$ & $\mathbf{0}$ & & 3.58 & 17.6 & 13.2 & 7.52 \\
\hline $\mathbf{0}$ & 1 & $\mathbf{0}$ & & 4.50 & 27.2 & 17.3 & 10.9 \\
\hline $\mathbf{0}$ & 2 & $\mathbf{0}$ & & 5.30 & 34.7 & 20.2 & 16.3 \\
\hline $\mathbf{0}$ & 3 & $\mathbf{0}$ & & 6.38 & 36.5 & 19.4 & 18.7 \\
\hline $\mathbf{0}$ & $\mathbf{0}$ & 1 & & 5.60 & 40.6 & 20.0 & 16.2 \\
\hline $\mathbf{0}$ & $\mathbf{0}$ & 2 & & 4.22 & 20.4 & 17.6 & 16.7 \\
\hline $\mathbf{0}$ & $\mathbf{0}$ & 3 & & 5.13 & 22.6 & 17.4 & 18.6 \\
\hline \multicolumn{4}{|c|}{ LSD 5\% } & 2.09 & 16.3 & 5.43 & 4.20 \\
\hline
\end{tabular}

Means with the same letters in the same column are not significantly different according to least significant difference test (LSD) $5 \%$

\section{REFERENCES}

Ajitomi, A., Y. Inoue, M. Horita and K. Nakaho (2015). Bacterial wilt of three Curcuma species, $C$. longa (turmeric), C. aromatica (wild turmeric) and C. zedoaria (zedoary) caused by Ralstonia solanacearum in Japan. J. Gen plant pathol. 81(4): 315-319.

Anoop, K., R. Suseela Bhai and K. Shiva (2014). Survey on the incidence of rhizome rot disease in major turmeric growing tracts of south India and isolation of associated organisms. Indian J. Advan. Plant Res. 6(1): 17-23.

Antoniazzi, D., de Souza Ferrari, M. P.; Nascimento, A. B.; Silveira, F. A.; Pio, L. A. S.; Pasqual, M. and H. M. Magalhães (2016). Growth regulators, DNA content and anatomy in vitrocultivated Curcuma longa seedlings. Afr. J. Biotech. 15(32): 1711-1725.

Babu, N. K., K. Samsudeen, M. Divakaran, G. S. Pillai, V. Sumathi, K. Praveen, P. N. Ravindran and K. V. Peter (2016). Protocols for In vitro Propagation, Conservation, Synthetic Seed Production, Embryo Rescue, Microrhizome Production, Molecular Profiling, and Genetic Transformation in Ginger (Zingiber officinale Roscoe.). Protocols for In vitro Cultures and Secondary Metabolite Analysis of Aromatic and Medicinal Plants, Second Edition: 403426.

Bhattacharya, M., A. K. Goyal and T. Mishra (2014). In vitro regeneration of some lesser known medicinal Zingibers: a review. Biol. Useful Plants and Microbes.

Bhosale, U., S. Dubhashi, N. Mali and H. Rathod (2011). In vitro shoot multiplication in different species of banana. Asian J. Plant Sci. Res. 1(3): 23-27.

Cheethaparambil, A., G. S. Pillai and I. Balachandran (2014). In vitro microrhizome and minirhizome production in turmeric (Curcuma longa L.) cultivar Alleppey Supreme and its comparative anatomical and histochemical analysis. Inter. J. Current Microbio. Applied Sci. 3(3): 535-542.
Chen, J., J. Zhao, D. L. Erickson, N. Xia and W. J. Kress (2015). Testing DNA barcodes in closely related species of Curcuma (Zingiberaceae) from Myanmar and China. Mol. Ecol. Resour.15(2): 337-348.

Christenhusz, M. J. M. and J. W. Byng. (2016). The number of known plants species in the world and its annual increase. Phytotaxa. 261(3): 201-217.

Das, A.; V. Kesari and L. Rangan (2010). Plant regeneration in Curcuma species and assessment of genetic stability of regenerated plants. Biol. Plantarum. 54(3): 423-429.

Deb, B. C. and S. Chakraborty (2017). Evaluation of genetic variability and characterization of some elite Turmeric genotypes in Terai region in India. Int J. Current Microbio. Appl. Sci. 6(5): 2357-2366.

Ghosh, A., P. Chatterjee and P. Ghosh (2013). A protocol for rapid propagation of genetically true to type Indian Turmeric (Curcuma longa L.) through in vitro culture technique. Adv. Appl. Sci. Res. 4(3): 39-45.

Gomez, K.A. and A. A. Gomez (1984). Statistical Procedures for Agricultural Research, $2^{\text {nd }}$ ed. John Wily, NY., $680 \mathrm{p}$

Goyal, A.; K. Ganguly, T. Mishra and A. Sen (2010). In vitro multiplication of Curcuma longa Linn.an important medicinal zingiber. North Bengal Univ. Jo. Plant Sci. 4: 21-24.

Gupta, S. D. and Y. Ibaraki (2006). Plant tissue culture engineering. P.480. Springer Netherlands. ISBN: 9781402036941.

Herdt, R. W. (2006). Biotechnology in agriculture. Ann. Rev. Enviro. Resour. 31: 265-295.

Ilyas, S.; E. R. Palupi and A. D. Susila (2016). Growth, yield and quality of ginger from produced through early senescence. Int. J. Appl. Sci. Technol. 6(1): 21-28.

Jasim, B., A. A. Joseph, C. J. John, J. Mathew and E. Radhakrishnan (2014). Isolation and characterization of plant growth promoting endophytic bacteria from the rhizome of Zingiber officinale. Biotechnol. 4(2): 197-204. 
Khalafalla, M. M., H. M. Daffalla, E. Abdellatef, E. Agabna and H. A. El-shemy (2011). Establishment of an in vitro micropropagation protocol for Boscia senegalensis (pers.) Lam. ex Poir. J. Zhejiang Univ. Sci. B 12(4): 303312.

Lamo, J. M. and S. R. Rao (2017). Meiotic behaviour and its implication on species inter-relationship in the genus Curcuma (Linnaeus, 1753) (Zingiberaceae). Comparative Cytogenetics. 11(4):691-702.

McDonald, J. H. (2014). Handbook of Biological Statistics. Sparky House Publishing, Baltimore, Maryland. (3rd ed.). This web page contains the content of pages 1-2. Online: http://www.biostathandbook.com/

Mohanty, P., S. Behera, S. S. Swain, D. P. Barik and S. K. Naik (2013). Micropropagation of Hedychium coronarium J. Koenig through rhizome bud. Physiol. Molecular Biol. Plants.19(4): 605-610.

Murashige, T. and F. Skoog (1962). A revised medium for rapid growth and bio assays with tobacco tissue cultures. Physiolo. Plantarum. 15(3): 473-497.

Prabhu, K. N.; V. Kantharaju, Y. Mahesh, T. Pushpa, and N. Thammaiah. (2018). Roving Survey for Turmeric Root-Knot Nematode in Major Districts of Karnataka, India. Int. J. Current Microbiol. Appl. Sci. 7(1): 901-910.

Raju, C. S.; A. Aslam and A. Shajahan. (2015). Highefficiency direct somatic embryogenesis and plant regeneration from leaf base explants of turmeric (Curcuma longa L.). Plant Cell, Tiss. Org. (PCTOC). 122(1): 79-87.
Ravindran, P. N. (2017). The Encyclopedia of Herbs and Spices. CABI. P.1176. ISBN: 9781780643151.

Ravindran, P. N. and K. N. Babu (2016). Ginger: The Genus Zingiber. CRC Press. P.576. ISBN: 9781420023367.

Ravindran, P. N., K. N. Babu and K. Sivaraman (2007). Turmeric: The Genus Curcuma.CRC Press. P.504. ISBN: 9781420006322.

Sarathi, V., S. kumar, R. kumar and A. Panneerselvam (2014). Studies on rhizome rot pathogen in Curcuma longa. Int. J. Current Microbiol. Appl. Sci. 3(8): 296-302.

Selvakkumar, C., A. Balakrishnan and B. S. Lakshmi (2007). Rapid in vitro micropropagation of Alpinia officinarum Hance, an important medicinal plant, through rhizome bud expiants. Asian J. Plant Sci. 6(8): 1251-1255.

Sumathi, V. (2014). Studies on somaclonal variations in zingiberaceous crops. Master Thesis. Department of Botany, Univ. Calicut. Online: http://shodhganga.inflibnet.ac.in/bitstream/106 03/27452/7/07_introduction.pdf.

Sunitibala, H., M. Damayanti and G. J. Sharma (2001). In vitro propagation and rhizome formation in Curcuma longa Linn. Cytobios. 105(409): 7182.

Yadav, R. P. and G. Tarun (2017). Versatility of turmeric: A review the golden spice of life. J. Pharmaco. Phytochem. 6(1): 41-46.

Yusuf, N. A., M. S. Annuar and N. Khalid (2011). Rapid micropropagation of Boesenbergia rotunda (L.) Mansf. Kulturpfl.(a valuable medicinal plant) from shoot bud explants. Afr. J. Biotechnol.10(7): 1194-1199.

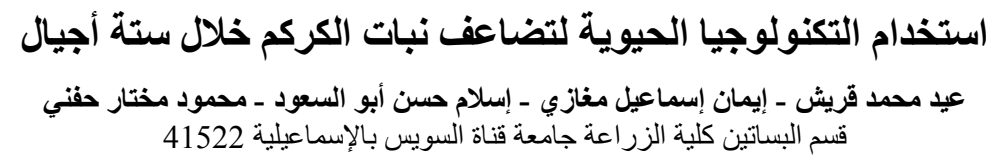

الهدف من هذه الدر اسة هو تأسيس بروتوكول لإنتاج نبات الكركم Curcuma longa L معمليا. تم استخدام البر اعم المنبتة من نبات الكركم كمنفصل

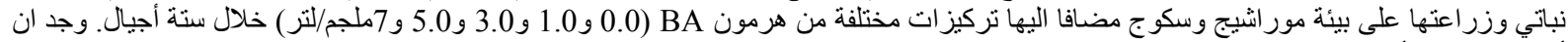

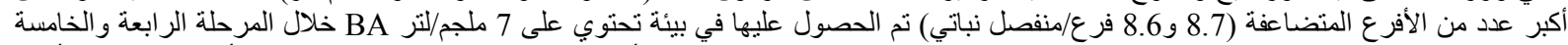

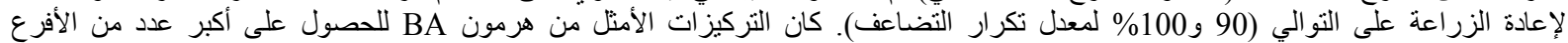

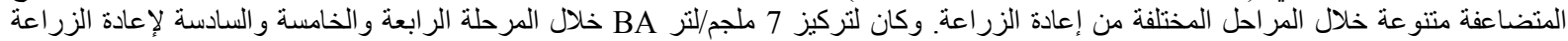

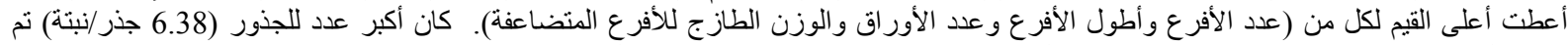

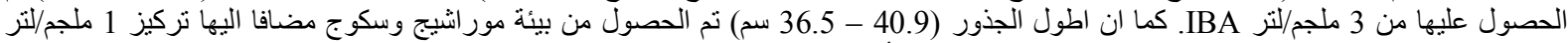

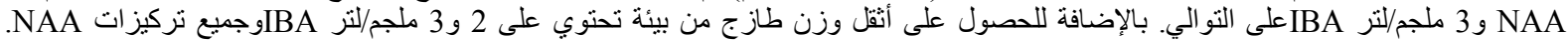

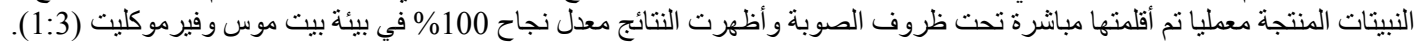

